\title{
Sosyal Ağlara Dayalı Öğrenme Algısı (SAD) Ölçeğinin Geliştirilmesi: Geçerlik ve Güvenirlik Çalışması*
}

\section{Development Of Social Networks-Based Learning Perception Scale: Validity And Reliability Study}

\author{
Gürol YOKUŞ**, Tuğba YANPAR YELKEN***
}

Öz: Günümüzde oldukça yaygınlık kazanan sosyal ağların öğrenme amaçlı kullanılması informal öğrenme açısından bakıldığında oldukça önemli ve değerli görülmektedir. Sosyal ağların ve sosyal medya uygulamalarının artık Sosyal Web (Web 2.0) olarak adlandırılan bir dünyanın parçası haline geldiği, eğitimcilerin öğrenme eylemini bireye özgü ve kişiselleştirebilir hale getirmeye çabaladığ görülmektedir. $\mathrm{Bu}$ araştırmanın amacı, sosyal ağlar üzerinde gerçekleşen öğrenmelerin belirlenmesine yönelik bir ölçek geliş̧tirmektir. Alanyazın taraması ve öğretmen adaylarıyla yapılan tartışmalar sonucunda 47 maddeden oluşan bir madde havuzu oluşturulmuştur. Uzman kanısı için 6 uzmandan 7'li derecelendirme ile görüşleri alınmış; sonrasında ise ölçek ve maddelere ilişkin kapsam geçerlilik indeksi hesaplanmıştır. Ölçek iki gruba ayrılmış ve yapı geçerliği için 350 kişilik çalışma grubu ile açımlayıcı faktör analizi, 325 kişilik grupla doğrulayıcı faktör analizi yapılmıştır. Ortaya konulan model, DFA ile doğrulandıktan sonra, Sosyal Ağlara Dayalı Öğrenme Algısı Ölçeği 20 maddelik dört faktörlü bir ölçek olarak geliştirilmiştir. Sosyal Ağlara Dayalı Öğrenme Algısı Ölçeğinin Cronbach Alpha güvenirlik katsayısının $(\alpha)=.90$ $(\alpha)=.90$, Kişiselleştirme alt boyutunda $(\alpha)=.921$, Paylaşım alt boyutunda $(\alpha)=.888$, Etkileşime dayalı öğrenme alt boyutunda $(\alpha)=.704$, Kullanım kolaylığı alt boyutunda $(\alpha)=.701$ olduğu ve açıklanan varyansın (\% 58.14) değerlerine sahip olduğu görülmektedir. Ayrıca, Pearson Moment Korelasyon analizi sonucunda maddelerin toplam puanla yüksek düzeyde ilişki gösterdiği görülmektedir. Modifikasyon indeksleri yardımı ile ideal değerlere ulaşan tek faktörlü yapı, Sosyal Ağlara Dayalı Öğrenme Algısı Ölçeğinin geçerli ve güvenilir olduğunu, ileride yapılacak araştırmalarda kullanılabileceğini göstermiştir. Anahtar Kelimeler: Sosyal ağlara dayalı öğrenme algısı, sosyal web, kolektif akıl, ölçek geliştirme

\footnotetext{
Abstract: The use of social networks, which have become widespread nowadays for learning purposes is seen as important and valuable in terms of informal learning. It is seen that social networks and social media applications are now becoming part of a world called Social Web (Web 2.0) and educators attempt to make learning unique and customized. This research aims to develop a scale for determining how learning is actualized on social networks. A pool of 47 items was created as a result of literature review and discussions with pre-service teachers. For expert view, 6 experts gave their ideas using 7 point likert scale. Then, validity index of the each item and overall scale were calculated. Scale applied to two different groups. For the construct validity of the scale, exploratory factor analysis was conducted with data collected from 350 pre-service teachers and confirmatory factor analysis was done with another study group including 325 pre-service teachers. After the model was verified with confirmatory factor analysis, the Social Networks-Based Learning Perception Scale was developed as a 20 - item four-factor scale. Cronbach Alpha coefficient correlation was found out to be $(\alpha)=.90$ and explained variance to be (\%58.14). Additionally, Pearson Moment Correlation analysis showed that there was a high level of correlation between individual items and overall score. The four-factor structure, which shows the ideal values with the help of modification indexes, indicate that the Social Networks- Based Learning Perception Scale is valid and reliable and can be used in future research.

Keywords: Social networks-based learning perception scale, social web, collective mind, scale development

* Sosyal Ağlara Dayalı Öğrenme Algısı (SAD) Ölçeği, birinci yazarın doktora tez çalışması kapsamında geliştirilmiştir.

** Dr., Sinop Üniversitesi, Eğitim Fakültesi, Sinop-Türkiye, ORCID: 0000-0002-4849-5829, e-posta: gurolyokus@gmail.com

***Prof. Dr. Mersin Üniversitesi, Eğitim Fakültesi, Mersin-Türkiye, ORCID:0000-0002-0800-4802, e-posta:

tyanpar@gmail.com
} 


\section{Giriş}

Günümüzde oldukça yaygınlık kazanan sosyal ağların öğrenme amaçlı kullanılması informal öğrenme açısından bakıldığında oldukça önemli ve değerli görülmektedir. Sosyal ağlar bir topluluğun bir amaç doğrultusunda bir araya gelmesini içerdiği için topluluğun ihtiyaç ve amaçlarının belirgin bir şekilde ortaya konulması sosyal ağların öğrenme üzerindeki etkililiği açısından oldukça kritik rol oynamaktadır. Sosyal ağlar içerisinde topluluklar kendilerine ait değerler ve dil geliştirebilmekte ve topluluk üzerinden üretilen katma değerleri ve kültürü bu dil ve platform aracılığg ile diğer yeni sosyal ağ üyelerine iletebilmektedirler. Kaplan ve Haenlein (2010) sosyal ağlar kavramının artık bireylerin gündeminin başına oturduğunu, danışmanlardan karar verme konumundaki yöneticilere kadar herkesin Wikipedia, YouTube, Facebook, Second Life, Twitter gibi uygulamalardan en etkin şekilde nasıl yararlanılabileceğini araştırdığını ifade etmektedirler. Aynı şekilde, Jovanovic, Chiong ve Weise (2012) günümüzde öğrencilerin ve eğitimcilerin artık Facebook, Twitter, Wikipedia ve YouTube dünyalarında yaşadıklarını, bunlar ve diğer sosyal ağların ve sosyal medya uygulamalarının artık Sosyal Web (Web 2.0) olarak adlandırılan bir dünyanın parçası haline geldiklerini belirtmektedir. Onlara göre, sosyal ağlar ve sosyal medya uygulamaları yani Sosyal Web, "sosyal etkileşim", "içerik paylaşımı" ve "kolektif ak1l" kavramlariyla temsil edilmektedir.

21. yüzyılda ortaya çıkan yeni dijital ortamları eğitim ortamlarında hızlı bir şekilde kabul görmektedir. Johnson, Levine ve Smith (2009) hazırladıkları Horizon (Ufuk) Raporunda, Google Dokümanlar, Vociethread, Twitter, Facebook ve Wordle gibi çevrimiçi ortamların ve araçların sayısında bir patlama yaşandığını, bunun yanında çevrimiçi bulut gibi inovasyonların da ortaya çıktığını belirtmişlerdir. Bu rapor kapsamında "eğitim kurumlarının dinamik yapıya sahip ve gittikçe artan bulut temelli hazır uygulamalardan yararlanmaya başladıkları" vurgulanmaktadır. Ayrıca bu raporda gelecek 5 yıl içerisinde, kullanıcı tarafından oluşturulan içeriklerin, sosyal ağların, mobil cihazların, sanal dünyaların, yeni yayın türlerinin ve çoklu oyunculu eğitsel oyunların kolej ve üniversite kampüslerini önemli derecede etkileyeceği vurgulanmıştır.

McLoughlin ve Lee (2010), sosyal temelli Web 2.0 araçlarının ve teknolojilerinin informal konuşma, yansıtıcı diyalog, işbirlikli içerik üretimini desteklediği ve pek çok fikir ve sunumlara erişim sağladığını belirtmişlerdir. Uygun kullanıldığında bu araçların, öğrenen ögesini destekleyerek, özerklik ve sosyal ağlara katılım sayesinde asıl kontrolü öğrenene verdiği vurgulanmıştır. Web 2.0 araçları öğrenenleri fiziksel, coğrafi, kurumsal ve organizasyonel sinırlardan bağımsız kılmaktadır. McLoughlin ve Lee'e göre, bu Web 2.0 temelli özdüzenlemeli öğrenmenin verimli olabilmesi için öğrenenlerin hangi araçları/içeriği seçebileceğini ve kişiselleştirebileceğini öğrenmeleri ve hangi yerlerden/kaynaklardan yardım alabileceklerini öğrenmeleri gerekmektedir. Sosyo-teknolojik temelli ortaya çıkan dijital uygulamalar daha kişiselleştirilmiş, daha sosyal ve daha katılım temelli eğitsel anlayışlara olan ihtiyacı gözler önüne sermektedir.

21. yüzyıl başlarından itibaren eğitimciler öğrenme eylemini bireye özgü ve kişiselleştirebilir hale getirmeye çabalamaktadırlar. Bununla ilgili olarak ağsal öğrenme, bağlantılı öğrenme kuramı gibi yaklaşımlar ön plana çıkmaktadır. Ağa dayalı öğrenme "öğrenenlerin birbirine bağlanması için (kendi aralarında, öğretmenleriyle, değerli öğrenme kaynaklarıyla) teknolojinin kullanıldığı işbirlikli çevrimiçi öğrenme biçimi” (Goodyear ve Yang, 2009); "Web üzerinde ve Web'in imkânları kullanılarak gerçekleşen öğrenme" (Delfino ve Persico, 2009); "öğrenenler, öğrenen-öğreticiler ve öğrenen-kaynaklar arasındaki bağlantılara odaklanan ve araştırmacı-uygulayıcı bir topluluk tarafından desteklenen ilişkisel bir yaklaşım" olarak (Parchoma, 2010) tanımlamışlardır. Bu çalışmada ise ağa dayalı öğrenme, Web teknolojilerine dayalı olarak öğrenme topluluklarındaki bireyler arasında karşılıklı güven, paylaşım ve uzmanlaşmaya dayalı bir bağlantılılık inşa edildiği ve bağlantıların çeşitli aktörlerle zenginleştirildiği sosyal öğrenme biçimi olarak tanımlanmaktadır.

Bağlantılı öğrenme ise dijital çağın gelişmelerini bireylerle buluşturmakta, olanaksız sanılan durumları bireylerin dünyalarına indirmekte ve akademik ihtiyaçları bireyin ilgileriyle bir araya getirmektedir. Öğrenenler, hayalini kurdukları kişi, akran veya önde gelen uzmanlarla 
kendi ilgileri doğrultusunda bağlantı kurmakta ve öğrenmelerini bağlantı yoluyla gerçekleştirmeyi tercih etmektedirler. Siemens (2005) ve Killion'a (2011) göre bağlant1l1lık, bir öğrenme teorisidir; bu öğrenme teorisi öğrenmenin ve bilginin fikirlerin farklılığında yatan bağlantıların oluşturulması yoluyla gerçekleştiğini vurgulamaktadır. Kumpulainen ve SeftonGreen (2012), bağlantılı öğrenme teorisini, son yıllarda popülerleşen ve öğrenmeyi formal ve informal toplulukların ötesinde geçen holistik bir deneyim olarak gören bir model olarak ele almaktadırlar. Kumpulainen ve diğerlerinin çalışmasında bağlantılı öğrenme, "öğrenenleri anlama, izleme, keşfetme, zaman-mekân ikilisi, sınırların ötesine geçme, metinlerarasılık ve öğrenen yaşamlar" ile ilişkilendirilmektedir.

Ağa dayalı öğrenme teorisinde bireyler organizasyonlar ve kurumlara bilgi akışı sağlamakta, ağ dügümleri bilgi değiş-tokuşunda geri dönüşüm olarak bireye akış sağlamakta ve sürdürülebilir öğrenmeyi sağlamaktadır (Siemens, 2005). Ryberg, Buus ve Georgsen (2012), ilişki ve bağlantı kurma eylemi ve öğrenmenin, bireyin zihniyle ya da öğrenenlerin kendisiyle sınırlandırılamayacağını iddia etmektedir. Öğrenme ve bilginin inşası, öğrenenler-öğreticilerkaynaklar arasında oluşturulan bağlantı ve etkileşimlerde yatmakta; eleştirel diyalog ve sorgulamadan doğmaktadır. Aynen bu durumda olduğu gibi, ağa dayalı öğrenme teorisi de öğrenmeyi "sosyal \& ilişkisel olgu, etkileşim ve diyalog yoluyla inşa edilen bilgi anlayışı ve kimlik" olarak kabul etmektedir (Ryberg ve diğerleri, 2012).

Margolis ve Parboosingh (2015) sosyal ağların bir bağlam içerisinde (bir organizasyon, topluluk, meslek gibi) ve belirli amaçlar doğrultusunda (sürdürülebilir mesleki gelişim gibi) var olduğuna vurgu yapmakta; ağ yapılarının belirli olası amaçlar doğrultusunda farklılaşabileceği belirtmektedir. Margolis ve diğerlerine (2015) göre ortak ilgi ve uygulamalara sahip mesleki uzmanlar -aynı karmaşık uyumsal sistemlerde aktörlerin davrandığı gibi- ağlar oluşturabilir, bu ağlarda kolektif bir biçimde çeşitli amaçlar edinebilir; bilinçli ya da bilinçsiz bir şekilde bir yönetim süreci sergileyebilir, ağlarının istikrarını sağlayabilir, amaçları doğrultusunda önemli olan organizasyonlar ve topluluklarla uygun bağlantılar kurabilir, güvene ve katılıma dayalı olmak koşuluyla üyeler arası etkileşimi teşvik edebilirler. Ito ve diğerleri'e (2013) göre en etkili ve anlamlı öğrenme biçimleri, öğrenenlerin zengin sosyal desteğe erişebildiği, konu alanının ilgili olduğu ve etkileşime izin verdiği öğrenme durumlarıdır. Bağlantılı öğrenme, farklı bilgi, kültür ve sosyal uygulama alanları arasındaki birleşim üzerinde odaklanmaktadır; yani sosyal, ilgi temelli ve formal eğitim alanıyla motivasyon ve içeriği bir araya getirerek anlamlı ve sürdürülebilir öğrenmeyi sağlamaktadır.

Jovanovic ve diğerleri, sosyal ağların eğitim açısından ne derecede etkili araçlar olduğu konusunda hala alan yazında çalışmaların eksik olduğunu belirtmektedir. Çeşitli çalışmalarda bu endişe dile getirilmektedir (Ala-Mutka ve diğerleri, 2009; Christensen, Johnson ve Horn, 2008; Johnson, Levine ve Smith 2017; Minocha, 2009). Örneğin, Armstrong (2012) sosyal ağların öğrenciler açısından birtakım dezavantaj ve riskler içerdiğini vurgulamaktadır. Ona göre, öğrenciler belirli bir konuyu öğrenmek ve bilgiyi uzun süreli belleklerinde tutmak yerine sosyal medya platformlarında erişilebilir halde olan bilgi kolayca erişebilmekte ve öğrenme deneyimi yerine bunun erişimin kolaylığını yaşamayı tercih etmektedirler. İkinci risk, öğrencilerin çoklu görevleri birarada yapmaya çalışmalarıdır. Ders çalışma etkinliği sırasında çeşitli sosyal medya araçlarının kullanımı akademik performansta azalmaya yol açmakta, konsantrasyon eksikliği ve dikkat dağınıklığı sorunları ortaya çıkmaktadır. Üçüncü risk, öğrencilerin sosyal ağlarda fazla zaman geçirirken, insanlarla sosyalleşmek için daha az zaman ayırmasıdır. Dördüncü risk ise sosyal ağların popülerleşmesiyle bilginin hızlı bir şekilde yayınlanmasıdır. Bu ise dil bilgisi, noktalama, yazım kuralları gibi etkili yazma becerilerinin olumsuz etkilenmesine yol açmaktadır. Bu dördüncü riskte göz önünde bulundurulması gereken başka noktalar da vardır. Aslında yazma becerilerinin olumsuz etkilenmesine yol açan, bilginin hızlı bir şekilde yayınlamasından ziyade kontrolsüz bir şekilde yayınlanması ve ağların kullanıcıya imkân tanıdığ 1 araçların sınırlılığ 1 olduğu düşünülmektedir. Ayrıca, sosyal ağlarda bilginin hızlı bir şekilde yayınlanmasının yol açtığ değersizleşmesi, alan yazının yıpratılması ve hangi bilginin değerli olduğu ve değerli bilgiye nasıl erişilebileceği sorusunun anlamını yitirmeye başlamasıdır. Sosyal ağların kendine özgü 
dezavantajlarını göz önünde bulundurup çeşitli önlemler almak mümkündür. Hung ve Yuen'un (2010) da belirttiği gibi öğrenmenin gerçekleşmesi için ideal/uygun ve doğal ortamlar oluşturabilmeleri için eğitimcilerin, Web 2.0 platformunun öğretimsel amaçlı kullanımını öğrenmeleri ve etkin şekilde faydalanmaları gerekmektedir.

Genel olarak incelendiğinde barındırdığı risklere rağmen çevrimiçi etkileşim sağlayan sosyal ağların eğitsel kullanımlarının pek çok araştırmacı tarafından desteklendiği görülmektedir (Barbour ve Plough, 2009; Holmes ve O'loughlin, 2014; Jovanovic ve diğerleri, 2012; Luehmann ve Tinelli, 2008; Veletsianos, 2011; Webb, 2009). Sosyal ağlar kullanıcılarına yüksek düzeyde katılım ve grup işbirliği imkânları sağladığı etkileşime dayalı öğrenmeyi kolaylaştırmaktadır. Greenhow (2011) sosyal ağların eğitsel platformlar olarak kullanılmasını çok değerli bulmaktadır. Ona göre öğrenenlerin diğerleriyle sosyal bağlantılar kurması, fikirlerin paylaşılması, anlık geri dönüt imkânları, bu ağlarda çeşitli ürünlerin oluşturulması ve bir kimlik inşası sürecinin yer alması gibi faktörler bireylerin öğrenmesini desteklemektedir. Sonuç olarak, sosyal ağlar içerdikleri risk ve dezavantajlar göz önünde bulundurularak alınacak birtakım kararlar ve düzenlemeler sayesinde etkili öğrenme ortamlarına dönüşebilmektedirler. Potansiyel olarak sosyal ağların içerisinde barındırdığı etkileşim, dönüt, grup aidiyeti, bilgiye erişim kolaylığı, içeriğin yeniden üretilebilmesi, içeriğin paylaşım kolaylığı gibi öğrenme deneyimleri sayesinde sosyo-kültürel açıdan çok önemli firsatlar sağlamaktadır. Sosyal ağlardan etkili bir şekilde yararlanmak için bu ağlar gelişigüzel kullanıma bırakılmamalı, eğitsel olarak anlamlı deneyimlere izin verecek şekilde etkinlikler tasarlanmalı ve kullanıcılar sosyal ağları akademik ve mesleki öğrenme amaçlı nası kullanabilecekleri konusunda bilinçlendirilmelidirler.

\section{Yöntem}

$\mathrm{Bu}$ bölümde sosyal ağlara dayalı öğrenme algısını ölçmeyi amaçlayan bir ölçek geliştirme çalışması yürütülmüştür. "Sosyal Ağlara Dayalı Öğrenme Algısı Ölçeği” geliştirme çalışmasının hangi aşamalarda gerçekleştiği ve çalışma grubunun özellikleri aşağıda sunulmuştur.

\section{Çalışma grubu}

Bu ölçek geliştirme çalışması, Akdeniz Bölgesinde yer alan bir devlet üniversitesinde Eğitim Fakültesinde 6 farklı programa kayıtlı olan toplam 675 öğretmen adayı üzerinde yapılmıştır. Çalışma grubunun \%59'u kadın, \%41'i ise erkektir. Ölçek iki gruba ayrılmış ve 350 kişilik çalışma grubu ile Açımlayıcı Faktör Analizi, 325 kişilik grupla Doğrulayıcı Faktör Analizi yapılmıştır. Çalışmaya katılan öğretmen adaylarının yaş aralığı 17 ile 27 arasında değişmektedir. Çalışma grubu bölümlerine göre yüzdelik olarak Tablo 1'de verilmektedir:

Tablo 1.

Ölçek Geliştirme Aşamasında Yer Alan Çalışma Grubu

\begin{tabular}{llll}
\hline Değişken & Grup & $\mathrm{N}$ & $\%$ \\
\hline Cinsiyet & Kadın & 402 & $\% 59$ \\
& Erkek & 273 & $\% 41$ \\
\hline Öğrenim Görülen Bölüm & Sinıf Eğitimi & 270 & $\% 40$ \\
& Okul Öncesi Eğitimi & 145 & $\% 21$ \\
& Fen ve Teknoloji Eğitimi & 130 & $\% 19.5$ \\
& PDR & 130 & $\% 19.5$ \\
\hline Sinıf Düzeyi & 1. Sinıf & 115 & $\% 17$ \\
& 2. Sinıf & 153 & $\% 23$ \\
& 3. Sinıf & 200 & $\% 29.5$ \\
& 4. Sinıf & 207 & $\% 30.5$ \\
\hline Yaş & $16-19$ & 107 & $\% 15$ \\
& $20-23$ & 508 & $\% 75$ \\
& $24-27$ & 60 & $\% 10$ \\
\hline Toplam & & 675 & 100 \\
\hline
\end{tabular}




\section{Sosyal Ağlara Dayalı Öğrenme Algısı Ölçeği’nin geliștirilmesi}

Ölçek geliştirmenin ilk aşamasında alanyazın incelenerek sosyal ağlar ve öğrenme ile ilgili yapılan çalışmalar incelenmiştir. Bu kapsamda yurt içi ve yurtdışında yapılan çalışmalara ulaşma amaciyla YÖK Tez Merkezi (2016), ProQuest (2016), Google Scholar, SpringerLink gibi (2016) veri tabanları taranmıştır. Bu veri tabanlarında beş ay boyunca düzenli aralıklarla tarama yapılmıştır. Bu veri tabanlarında arama yaparken "sosyal ağlar ve öğrenme", "web 2.0 ve öğrenme", "sosyal medya ve öğrenme", "social networks and learning" ve "social media and learning" anahtar kavramlarıyla arama yapılmıştır. Ulusal ve uluslararası alan yazında bu konuda yapılan çeşitli çalışmalar bulunmuştur. Ölçek geliştirilirken temel olarak Batchelder (2010), Ekici (2012), Gikas (2013), Knezek, Mills ve Wakefiled (2012), Mills, Knezek ve Wakefield (2013) ve Sabimbona (2013) tarafından yapılan çalışmalar esas alınmıştır. İlgili çalışmalar incelendikten sonra 10 öğretmen adayıyla "sosyal ağlarda öğrenmenin nasıl gerçekleştiği" hakkında tartışma yapılarak, katılımcıların görüşlerine dayalı göstergelere ulaşılmaya çalıșılmıștır. Dikkat çeken ve sıklıkla belirtilen ifadeler tespit edilerek ölçek ifadesine dönüştürülmüştür. Genellikle ölçekte kullanılması tasarlanan madde sayısının, olanak varsa üç-dört katının hazırlanmış olması (Tezbaşaran, 1996) arzu edildiğinden 3'ü olumsuz, 44'ü olumlu olmak üzere toplam 47 maddelik bir havuz oluşturulmuştur. Oluşturulan 47 maddelik ölçek deneme formu için uzman görüşleri alınmıştır. Ölçeğin deneme formu, teknoloji destekli öğretim, çevrimiçi ortamlarda sosyal buradalık, TPACK ve öğretmen eğitimi gibi konularda bilgi sahibi olan ve öğretmen adaylarıyla çeşitli çalışmalar gerçekleştiren Bilgisayar ve Öğretim Teknolojileri Eğitimi alanından 2 uzman, Eğitim Programları ve Öğretim alanından 2 uzman, Ölçme ve Değerlendirme alanından 1 uzman ve Türkçe Eğitimi alanından 1 uzman tarafından değerlendirilmiştir. Uzmanların görüşlerinin alınabilmesi için yedili derecelendirme kullanılmıştır. En son olarak, sadelik, rahat anlaşılırlık, netlik ve akademik dile uygunluk gibi kriterler açısından bir dil uzmanından görüş alınmış ve bu doğrultuda görüşme formundaki maddeler düzeltilmiştir.

\section{Kapsam geçerlik indeksinin belirlenmesi}

Kapsam geçerliliği oluşturulan her bir test maddesinin ölçülmek istenen beceriyi ne derece temsil ettiği ilgili bir kavramdır (Cronbach ve Meehl, 1955). Bir ölçme aracının kapsam geçerliğini değerlendirmek için (1) her bir maddenin kapsam alanını temsil gücü ve ayrıca (2) tüm maddelerin kapsam alanını temsil gücüne ilişkin uzman görüşleri alınır (Thorndike ve Haggen, 1977). Ölçekte yer alacak maddelerin yapıyı temsil gücünün yüksek olması, yap1 geçerliliği için oldukça önemlidir. Maddelerin kapsam geçerliliği uzman kanısı alınarak ve kapsam geçerlilik indeksi hesaplanarak her bir maddenin yapının bütünüyle olan uygunluğu belirlenmiş ve birtakım maddelerin düzeltilmesi/atılması işlemi yapılmıştır. Uzman kanısı için 6 uzmandan 7'li derecelendirme ile (tamamen uygun (7), oldukça uygun (6), kısmen uygun (5), kararsızım (4), kısmen uygun değil (3), hiç uygun değil (2), çıkartılmalı (1)] görüşleri alınmış; sonrasında ise ölçek ve maddelere ilişkin kapsam geçerlilik indeksi hesaplanmıştır. Kapsam geçerlik indeksinin belirlenerek istatistiksel temellere dayalı bir madde atımı veya düzeltme işlemi, yapı geçerliliğinin maddeler tarafından temsil edilme gücünü artıracağını ifade etmek mümkündür. Bu çalışmada hesaplama kolaylığı, yorumlama kolaylığı, hem madde hem ölçeğe ilişkin değer vermesi, tutarlılık ve güvenirliğe değil uzman uyuşumuna odaklanması, şansa bağlı uyuşumların elimine edilmesi gibi gerekçelerle "uyarlanmış kappa" tercih edilmiştir. $\mathrm{KGI}_{\mathrm{m}}$ hesaplanmasında Waltz ve diğerleri (2010) tarafindan önerilen madde kapsam indeksleri toplamı/madde sayısı; KGİ hesaplanmasında "uyarlanmış kappa" (Polit, Beck ve Owen, 2007); maddelerin değerlendirilmesinde ise Cicchetti ve Sparrow (1981) tarafindan geliştirilen standartlar benimsenmiştir. Madde atımında izlenen yol aşama aşama aşağıda belirtilmiştir:

Aşama 1: 47 pilot ölçek maddesi geliştirme

Aşama 2: Uzman değerlendirmesi $(\mathrm{n}=6)$

$\mathrm{KGI}_{\mathrm{m}}<0.78$ (Kapsam gerçerlilik indeksi 0.78 'den düşük olan 12 maddenin çıkarılması)

Aşama 4: Pilot formun nihai haline karar verilmesi (35 madde) 
Madde kapsam indeksi için 0.78 'den düşük kappa değerine sahip maddeler ölçeğe alınmamış ve ölçekteki en düşük maddenin $\left(\mathrm{KGI}_{\mathrm{m}}=0.81\right)$ kappa değerine sahip olduğu görülmüștür. Bu değer Cicchetti ve Sparow (1981)'e göre mükemmel ve iyi olarak görüş birliği yapılan maddelerdir. Ölçeğin tamamına ilişkin kapsam geçerlik katsayısı ise $\left(\mathrm{KGI}_{\mathrm{m}}=0.88\right)$ olarak bulunmuştur. Ölçeğin kapsam geçerliliğinin oldukça yüksek olduğu görülmektedir. 35 maddelik formda likert tipi ölçekleme yaklaşımlarından 7'li likert ölçeği [tamamen katılıyorum (7), oldukça katılıyorum (6), kısmen katılıyorum (5), kararsızım (4), kısmen katılmıyorum (3), çoğunlukla katılmıyorum (2), hiç katılmıyorum (1)] kullanılmıştır. Sosyal ağlara dayalı öğrenme algısını ortaya çıkarmayı amaçlayan bu çalışmanın kapsam açısından geçerli olduğu uzmanlarca belirtilmiştir.

\section{Verilerin analizi}

Verilerin önizlemesi için verilerin analizi yapılmadan önce uç (extreme), sapan (outlier), eksik (missing) veya hatalı değerler düzeltilmiştir. Toplam 675 öğretmen adayından gelen veriler doğrultusunda ölçeğin geçerlik ve güvenirlik çalışmaları yapılmıştır. Bu ölçek geliştirme çalışmasında çalışma grubundan elde edilen 675 gözlem ikiye bölünerek ilk grup üzerinde Açımlayıcı Faktör Analizi (n=350), ikinci grup üzerinde ise Doğrulayıcı Faktör Analizi ( $n=325)$ çalışmaları yapılmıştır.

Varsayımların kontrolü: İlk grupta yer alan gözlemlerle ilgili faktör analizi işlemleri ve gruplanmamış verilerin hazırlanması için gerekli varsayımların kontrolü sağlanmıştır. $\mathrm{Bu}$ amaçla kayıp değerler, örneklem büyüklüğ̈̈, tek yönlü uçdeğer, tek değişkenli normallik, çok yönlü uçdeğer, çok değişkenli normallik, doğrusallık ve çoklu bağlantı incelenmiştir.

Örneklem büyüklüğü: Faktör analizi için kontrol edilmesi gereken ilk ölçüt olarak örneklem büyüklüğü kontrol edilmiştir. Ölçek geliştirme sürecinde anlamlı ve güvenilir sonuçlara ulaşabilmek için çalışma grubunu oluşturan bireylerin sayısıyla ilgili farklı ölçütler önerilmiştir. Kline (1994) örneklem büyüklüğünün ölçekteki madde sayısının 10 katı kadar olması gerektiği belirtirken; Comrey ve Lee (1992) örneklem büyüklünün: ,n=100 olduğunda yetersiz, n=200 olduğunda orta düzeyde, $n=300$ olduğunda iyi ve $n=500$ olduğunda ise çok iyi ve 1000 'den fazla olması durumunda mükemmel olduğunu ifade etmiştir. Bu çalışmada örneklem büyüklüğünün madde sayısının ( $\mathrm{n}=35) 10$ katı $(\mathrm{n}=350)$ olduğu görülmektedir.

Kayıp değerler: Faktör analizine geçmeden önce gözlemler içerisinde katılımcıların eksik bıraktığı maddeler olup olmadığı kontrol edilmiştir. Verilerle ilgili kayıp değerlerin olduğu görülmüş ve kayıp değerlerin frekansına bakılmıştır. Toplamda yüzde 5-15 arasında oranında kayıp veri olduğu için (kayıp veri=yüzde 7), kayıp verilerin yerine serilerin ortalaması atanmıştır (Çokluk ve diğerleri, 2016).

Normallik: Verilerin basıklığı, normal dağılım eğrisinin diklik derecesini gösterir. Basıklık katsayısı pozitifse, eğri normale göre daha dik; negatifse normale göre daha basıktır. Analiz çıktısından elde edilen tanımlayıcı istatistikler tablosundaki basıklık ve çarpıklığa ait istatistik değeri standart hata değerine bölünerek bulunan değer $\% 5$ anlamlılık düzeyinde +1.96 ve -1.96 arasında olduğu gözlemlenmiştir. Dolayısıyla verilerin dağılımının tekli normalliği sağlanmıştır (Tabachnick ve Fidell, 2013). Çok değişkenli aykırı değerlerin analizi için de Mahalanobis uzaklığ karşılaştırılmıştır. Analiz sonucunda $\mathrm{p}<.001$ anlamlılık düzeyinde aykırı olan 28 gözlem olduğu görülmüş ve bu veriler analiz dışında bırakılarak 322 gözlemle analiz gerçekleştirilmiştir.

Doğrusallık: Doğrusallık varsayımı, değişkenler arası ve değişkenlerle faktörler arasındaki ilişkilerin doğrusal olmasını gerektirmektedir. Doğrusallık varsayımını test etmek için regresyon analizindeki artık grafikleri incelenmiştir. Artık grafiklerinde noktaların sıfır çizgisi etrafında kümelendiği görülmektedir. Ayrıca, çok değişkenli normallik ve doğrusallık için değişken 
çiftleri arasındaki doğrusallık testi "Saçılım grafiği” ile değerlendirilmiştir. Güçlü pozitif ve negatif çarpık olan değerlerin dağılım grafiği çizilerek doğrusallık kontrolü yapılmış ve elips şekline yakın bir şekil elde edildiği için çok değişkenli normallik ve doğrusallık şartının sağlandığı görülmüştür.

Çoklu bağlantı ve tekillik: Verilerle ilgili çoklu bağlantı ve tekilliğin yokluğu varsayımı kontrol edilmiştir. Çoklu bağlantı, test maddelerinin ikişerli olarak birbirleriyle yüksek derecede ilişkili olması durumudur. Bir değişkenin, başka bir değişkenin yerine geçebilecek kadar benzer olup olmadığını gösterir. Tekillik ise korelasyon katsayısının 1.00 olmasıdır (Şencan, 2005). Analiz sonucunda bir başka değişkenle .80 veya üzeri korelasyon ile birbiriyle sifır korelasyon olan değişkenlerin olmadığı gözlenmiştir. Son olarak, AFA grubundaki gözlemlerin araştırma kapsamında faktör analizine uygun olduğu varsayımı için Kaiser-Meyer Olkin [KMO] katsayısı ve Barlett Küresellik testi değerlendirilmiştir. Sosyal Ağlara Dayalı Öğrenme Algısı Ölçeğine ilişkin KMO ve Barlett Küresellik Testi Tablo 2'de yer almaktadır:

Tablo 2.

Sosyal Ağlara Dayalı Öğrenme Algısı Ölçeği KMO ve Bartlett Küresellik Testi

\begin{tabular}{lll}
\hline Kaiser-Meyer-Olkin Örneklem Yeterliliği & & .924 \\
\hline \multirow{3}{*}{ Bartlett Küresellik Testi } & Ki-kare değeri & 9074,288 \\
& Serbestlik derecesi & 780 \\
& $p$ & .000 \\
\hline
\end{tabular}

KMO testi, örneklem büyüklüğünün yeterliliğini ve dağılımın faktör analizi için yeterli olup olmadığını test etmektedir. Bulunan değer 1'e yaklaştıkça mükemmelleşmektedir. Bu değer 0.90 'larda mükemmel, 0.80 'lerde çok iyi, 0.70 'lerde ve 0.60 'larda orta, 0.50 'lerde kötü olarak değerlendirildiği belirtilmektedir (Çokluk ve diğerleri, 2016). Tablo 21 incelendiğinde bu araştırmada $\mathrm{KMO}$ değerinin mükemmel olduğu $(\mathrm{KMO}=0.92)$ bulunmuştur. Bartlett küresellik testi sonucu ise ki-kare değeri 9074,288 $(p<.001)$ bulunmuştur. Bartlett's değerinin anlamlı olması, verilerin çok değişkenli normal dağılımdan geldiklerini göstermektedir (Thompson, 2004).

\section{Bulgular}

\section{Açımlayıcı faktör analizi sonucu ve faktörlerin isimlendirilmesi}

Analizin ilk kısmında veri setinin faktör analizi için uygunluğu sınandıktan sonra sosyal ağlara dayalı öğrenme algısının yapı geçerliğini belirlemek için faktör çıkarma yöntemi belirlenmiştir. Faktör yapılarının belirlenmesi amacıyla kullanılabilecek farklı teknikler bulunmakla birlikte temel bileşenler analizi (Principal Component Analysis) alan yazında çok sık kullanılan yöntem olarak göze çarpmaktadır (Carmines ve Zeller, 1978; Klainbaum, Kupper ve Muller, 1987). Bu çalışmada temel bileşenler analizi gerçekleştirilmiş, faktörlerin birbiriyle ilişkisiz olduğu hipotezinden yola çıkılarak faktör döndürme yöntemi olarak dik döndürme (varimax rotation) işlemi yapılmıştır (Akbulut, 2010). İlgili alan yazında, faktör örüntüsünün oluşturulmasında 0.30 ile 0.40 arasında değișen faktör yüklerinin alt kesme noktası olarak alınabileceği belirtilmektedir (Büyüköztürk, 2009; Çokluk ve diğerleri, 2016). Bu çalışmada alt kesme noktası 0.40 alınmıştır. Sosyal Ağlara Dayalı Öğrenme Algısı Ölçeği'nin açımlayıcı faktör analizi sonucu elde edilen faktör yapısı ve faktör yük değerleri Tablo 3 'te sunulmaktadır: 
Tablo 3.

Sosyal Ağlara Dayalı Öğrenme Algısı Ölçeği Döndürülmüş Bileşen Matrisi

\begin{tabular}{|c|c|c|c|c|c|c|}
\hline & Faktö & & & & & \\
\hline & 1 & 2 & 3 & 4 & 5 & 6 \\
\hline S1 & ,805 & & & & & \\
\hline S3 & 800 & & & & & \\
\hline S2 & ,786 & & & & & \\
\hline S4 & ,762 & & & & & \\
\hline S6 & ,646 & & & & & ,485 \\
\hline S17 & 604 &, 516 & & & & \\
\hline S9 & 602 & & & & & \\
\hline S7 & ,586 & & & ,553 & & \\
\hline S24 & & ,787 & & & & \\
\hline S26 & & ,704 & & & & \\
\hline S25 & & ,702 & & & & \\
\hline S16 & & 685 & & & & \\
\hline S18 & & 628 & & & ,553 & \\
\hline $\mathrm{S} 23$ & & ,604 & & & & \\
\hline S19 & & ,597 & & & ,499 & \\
\hline S27 & &, 553 & ,453 & & & \\
\hline S29 & &, 775 & ,772 & & & \\
\hline S34 & & ,439 & 677 & & & \\
\hline S35 & & & ,675 & & & \\
\hline S31 & & & ,666 & & & \\
\hline S32 & & & ,661 & & & \\
\hline S33 & ,406 & ,412 & ,582 & & & \\
\hline S28 & & & ,560 & & & \\
\hline S12 & & & ,537 & ,438 & & \\
\hline S13 & & & ,459 & ,549 & & \\
\hline S8 & & & & 633 & & \\
\hline S14 & & ,412 & & ,505 & & \\
\hline S15 & & & & ,580 & & \\
\hline $\mathrm{S} 21$ & ,406 & ,436 & &, 570 & & \\
\hline S22 & & ,413 & & 533 & & \\
\hline S20 & & & & & ,851 & \\
\hline S10 & & & & & ,689 & \\
\hline S30 & & & & & ,577 & \\
\hline S5 & & & ,416 & ,436 & & \\
\hline S11 & & & & & & ,607 \\
\hline
\end{tabular}

Çıkarma Yöntemi: Temel Bileşen Analizi

Döndürme Tekniği:Varimax

a. Döngü sayısı 10.

Tablo 3'te görüldüğü gibi, analiz sonucunda 35 maddede ve özdeğeri 1'den yüksek olan altı faktörde toplanan ölçeğin sosyal ağlara dayalı öğrenme algısının yapısını açıkladığı toplam varyans miktarı \%73.09'tür. Ölçeğin maddelerinin Varimax dik döndürme yöntemiyle döndürülmüss faktör değerleri, 0.40 ile 0.85 yük değerleri arasında değişmektedir. Faktör analizi sonucunda elde edilen yük değeri, bir maddenin herhangi bir alt boyutta yer alıp almamasına ilişkin kullanılan kritik değeridir ve maddenin söz konusu faktörle olan ilişkisinin gücünü gösterir. Ayrıca maddelerin birden fazla faktör altında faktörlenmemesi göz önünde bulundurulmalıdır. Birden fazla faktöre girme ile ilgili alınabilecek ölçüt faktör yükleri 
arasındaki farkın en az 0,10 olmasıdır. İki faktördeki yük değeri bu kritik değerden az olan maddeler binişik maddeler olarak adlandırılmaktadır (Bütüner ve Gür, 2007). Faktör yük değeri 0,40 '1n altında olan maddelerle birlikte binişik olan 5, 12, 13, 14, 15, 18, 19 ve 29. maddeler ölçekten çıkarılmış ve tekrar faktör analizi yapılmıştır. Binişik olan ve bir faktör altında toplanmayan maddeler tekrar atılmıştır. Bu işlem birden fazla kez gerçekleştirilmiş̧tir. Sonuç olarak ölçek, özdeğeri 1'den büyük olan 20 madde, dört faktör altında toplanmıştır. Bu dört faktör ölçek varyansının \%58,14'ünü açılamaktadır. Ölçeğin özdeğerlerine ait çizgi grafiği incelendiğinde yapının aslında dört faktörlü olduğu görülmektedir. Sosyal Ağlara Dayalı Öğrenme Algısı Ölçeğine ilişkin Yamaç-Birikinti Grafiği Grafik 1'de yer almaktadır:

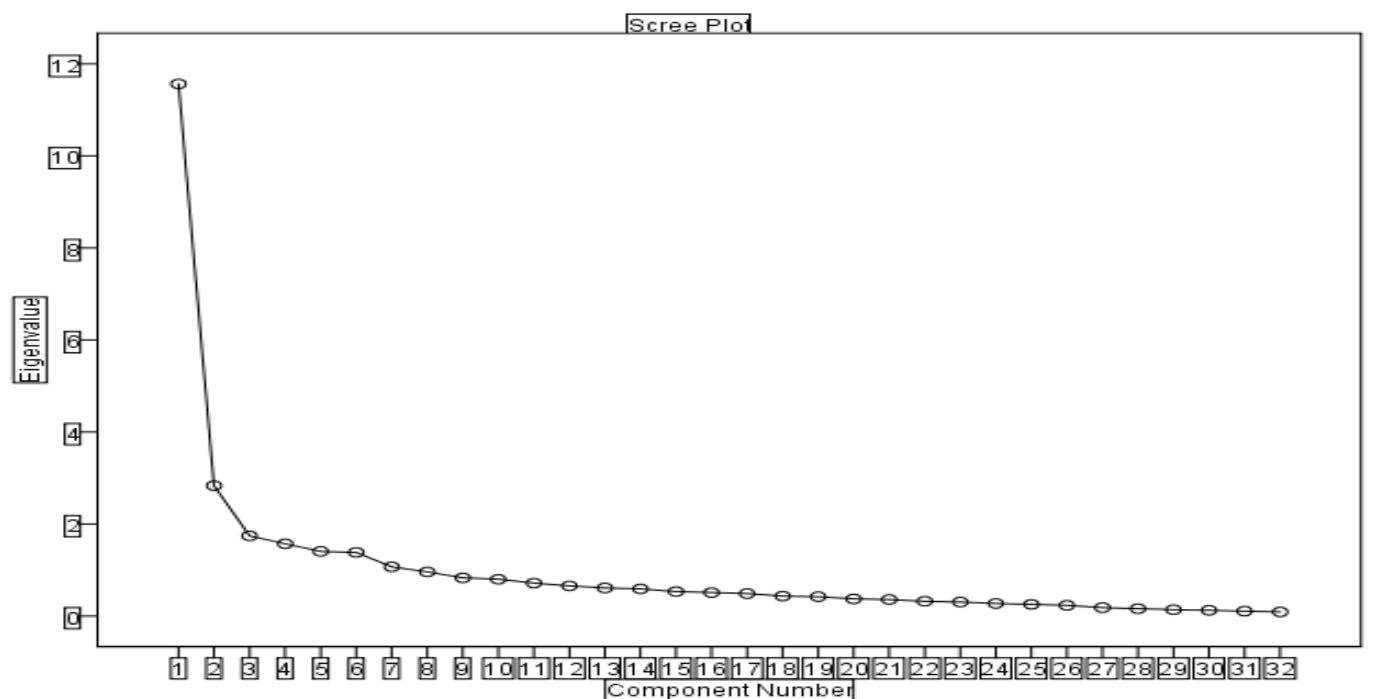

Grafik 1 Sosyal Ağlara Dayalı Öğrenme Algısı Ölçeğine İlişkin Yamaç Birikinti Grafiğgi

Grafikte, dördüncü faktörden sonra grafiğin genel gidişi plato şeklinde olup, önemli bir düşüş eğilimi gözlenmemektedir. Bu bakımdan ölçeğin dört faktörlü bir yapıya sahip olduğu söylemek mümkündür. Dört faktörlü ölçekte binişik madde yoktur. Ölçeği oluşturan maddelerle ilgili faktör yük değerlerine ilişkin matris incelenerek faktör yük değeri 0,40 'ın altında maddelerin olmadığı görülmüştür. Sonuç olarak, 20 maddelik ölçek formuna karar verilmiştir. İlk boyutta yer alan beş madde "Etkileşime dayalı öğrenme"; ikinci boyutta yer alan dört madde "Kullanım Kolaylığı"; üçüncü boyutta yer alan beş madde "Paylaşım"; dördüncü boyutta yer alan altı madde "Kişiselleştirme" faktörü olarak isimlendirilmiştir.

Açımlayıcı faktör analizi sonucunda faktör yapısına karar verildikten sonra, ölçeğin güvenirliği için Cronbach alfa katsayısı hesaplanmıştır. Güvenirlik bir ölçme aracında yer alan maddelerin birbirleri ile olan tutarlılığını ve kullanılan ölçeğin ilgilenilen sorunu ne derece yansıttığını ifade etmektedir. Bu araştırmada maddelerin birbiriyle tutarlı olup olmadığını belirlemede sık kullanılan Cronbach alfa iç tutarlılık katsayısı hesaplanmıştır. Bir ölçeğin güvenilir olduğunu söyleyebilmek için, hesaplanan iç tutarlılık katsayısının en az 0,70 olması gerektiğini belirtilmektedir (Liu,2003; Nunnally, 1978; akt. Tavşancıl, 2002). Sosyal Ağlara Dayalı Öğrenme Algısı Ölçeğine ilişkin güvenirlik analizi sonuçları Tablo 4 ve Tablo 5 'te yer almaktadır:

Tablo 4.

Sosyal Ağlara Dayalı Öğrenme Algısı Ölçeği Cronbach Alpha Güvenirlik Katsayısı

\begin{tabular}{llcc} 
& & Madde & Açılanan \\
& Cronbach Alpha & Sayıs1 & Varyans \\
\hline Sosyal Ağlara Dayalı Öğrenme Algısı Ölçeği & .905 & 20 & $\% 58,14$ \\
\hline
\end{tabular}


Tablo 5.

Sosyal Ağlara Dayalı Öğrenme Algısı Ölçeğinin Alt boyutlarına İlişkin Güvenirlik Katsayısı

\begin{tabular}{|c|c|c|c|c|}
\hline & $\begin{array}{l}\text { Cronbach } \\
\text { Alpha }\end{array}$ & $\begin{array}{l}\text { Madde } \\
\text { Say1s1 }\end{array}$ & $\begin{array}{l}\text { Standart } \\
\text { Sapma }\end{array}$ & $\begin{array}{l}\text { Aç1klanan } \\
\text { Varyans }\end{array}$ \\
\hline Kişiselleştirme & ,921 & 6 & 0,24 & $\% 32,18$ \\
\hline Paylaşım & 888 & 5 & 0,81 & $\% 9,62$ \\
\hline Etkileșime dayalı öğrenme &, 704 & 5 & 0,42 & $\% 8,21$ \\
\hline Kullanım Kolaylı̆̆ &, 701 & 4 & 0,49 & $\% 8,04$ \\
\hline
\end{tabular}

Güvenirlik kapsamında iç tutarlılığı test etmek için Cronbach Alpha değerlerine bakılmıştır. Tablo 4 incelendiğinde Sosyal Ağlara Dayalı Öğrenme Algısı Ölçeğinin Cronbach Alpha güvenirlik katsayısının $(\alpha)=.90$ olduğu, Tablo 5 'te ise Kişiselleştirme altölçeğinin güvenirliğinin $(\alpha)=.92$; Paylaşım altölçeğinin güvenirliğinin $(\alpha)=.88$; Etkileşime Dayalı Öğrenme altölçeğinin güvenirliğinin $(\alpha)=.70$ ve Kullanım Kolaylığı altölçeğinin güvenirliğinin $(\alpha)=.70$ olduğu; dolayısıyla Sosyal Ağlara Dayalı Öğrenme Algısı Ölçeğinin güvenirliğinin yüksek düzeyde olduğu görülmektedir. Ayrıca maddelerin birbiriyle yüksek düzeyde ilişki gösterip göstermediğini incelemek amaciyla Pearson Moment Korelasyon Analizi gerçekleştirilmiştir. Tablo 6'da madde-toplam madde korelasyonuyla ilgili Pearson Moment Korelasyon Katsayıları verilmektedir:

Tablo 6.

Sosyal Ağlara Dayalı Öğrenme Algısı Madde-Toplam

Madde Korelasyonu

\begin{tabular}{lll}
\hline Maddeler & Made-Toplam Korelasyonu (r) & $\mathrm{p}$ \\
\hline S1 & .587 & .000 \\
\hline S2 & .751 & .000 \\
\hline S3 & .705 & .000 \\
\hline S4 & .728 & .000 \\
\hline S5 & .703 & .000 \\
\hline S6 & .725 & .000 \\
\hline S7 & .725 & .000 \\
\hline S8 & .555 & .000 \\
\hline S9 & .409 & .047 \\
\hline S10 & .459 & .041 \\
\hline S11 & .472 & .041 \\
\hline S12 & .538 & .000 \\
\hline S13 & .728 & .000 \\
\hline S14 & .642 & .000 \\
\hline S15 & .623 & .000 \\
\hline S16 & .737 & .000 \\
\hline S17 & .717 & .000 \\
\hline S18 & .698 & .000 \\
\hline S19 & .541 & .000 \\
\hline S20 & .489 & .040 \\
\hline$*$ p $<05$ düzeyinde anlaml ${ }_{1}$ fark vardir.
\end{tabular}

$* \mathrm{p}<.05$ düzeyinde anlamlı fark vardır.

Tablo 6 incelendiğinde Pearson Momentler Korelasyon analizi sonucunda ölçekte yer alan tüm maddelerin, toplam puanla $\mathrm{p}<0.01$ düzeyinde madde toplam test korelasyonuyla anlamlı ilişki sergilediği ve bu ilişkinlerin 0.30 'dan büyük olduğu saptanmıştır. Dolayısı ile Sosyal Ağlara Dayalı Öğrenme Algısı Ölçeğindeki bütün maddelerin ayırt edici olduğu söylenebilir. 


\section{Doğrulayıcı faktör analizi}

Sosyal ağlara dayalı ögrenme algısıyla ilgili açımlayıcı faktör analizi sonucu elde edilen faktör yapısının uygunluğu sınamak için Doğrulayıcı Faktör Analizi (DFA) yapılmıştır. Doğrulayıcı faktör analizi, değişkenler arası ilişkilere dayalı olarak faktör ya da faktörleri keşfetmeyi amaçlamaktadır (Tabachnick ve Fidell, 2013). Araştırmada geliştirilen sosyal ağlara dayalı öğrenme algısı yapısıyla ilgili modelin doğrulanıp doğrulanmadığını görmek amacıyla uyum düzeylerine bakılmıştır. Doğrulayıcı faktör analizi, kuramsal bilginin sınanması ve/veya doğrulanması amacıyla kullanılmaktadır (Şencan, 2005). Doğrulayıcı faktör analizi için 335 kişilik başka bir grup üzerinde faktör analizi varsayımları kontrol edilmiş ve çoklu aykırı değer olarak bulunan 26 gözlem atılarak 309 gözlem üzerinde analiz yapılmıştır. Açımlayıcı faktör analizi sonucunda elde edilen 20 madde içeren dört faktörlü ölçeğe doğrulayıcı faktör analizi uygulanmıştır. Doğrulayıcı faktör analizi uygulaması sonuçları değerlendirilirken birden fazla uyum indeksinde yararlanılabilmektedir (Kline, 2011; Tabachnick ve Fidell, 2013). Model uygunluğunun değerlendirilmesinde kullanılan farklı uyum iyiliği indeksleri bulunmaktadır (Gizir, 2005). Doğrulayıcı faktör analizinin bir sonucu olarak, $\mathrm{X}^{2} / \mathrm{sd}$ oranı (ki-kare uyum iyiliği testi), GFI (iyilik uyum indeksi), AGFI (düzeltilmiş iyilik uyum indeksi), RMSEA (yaklaşık hataların ortalama karekökü), RMR (artık oranların karekökü), SRMR (artık ortalamaların karekökü), CFI (karşılaş- tırmalı uyum indeksi), NFI (normlaştırılmış uyum indeksi) ve NNFI (normlaştırılmamış uyum indeksi) uyum indeksleri dikkate alınarak değerlendirilmiştir. Doğrulayıcı faktör analizi için bu çalışmada Lisrel 8.70 kullanılmıştır.

Analiz sonucunda PATH diyagramı çizdirilerek modele ait değişkenler, $t$ değerleri, faktör yükleri ve uyum iyiliği değerleri incelenmiştir. $t$ değeri 1.96 'yı aştığında 0.05 düzeyinde anlamlı olması beklenmektedir (Schumacker and Lomax 2010). Elimizdeki modelde tüm maddelere ait $\mathrm{t}$ değerlerinin anlamlı olması modelin kabul edilebilir olduğunu göstermektedir. Doğrulayıcı faktör analizi sonucunda $t$ değerleri ve standartlaştırılmış çözüm değerleri incelenmiştir. Faktör analizi sonucunda, t değerlerine ilişkin path diyagramı Şekil 2'de verilmektedir:

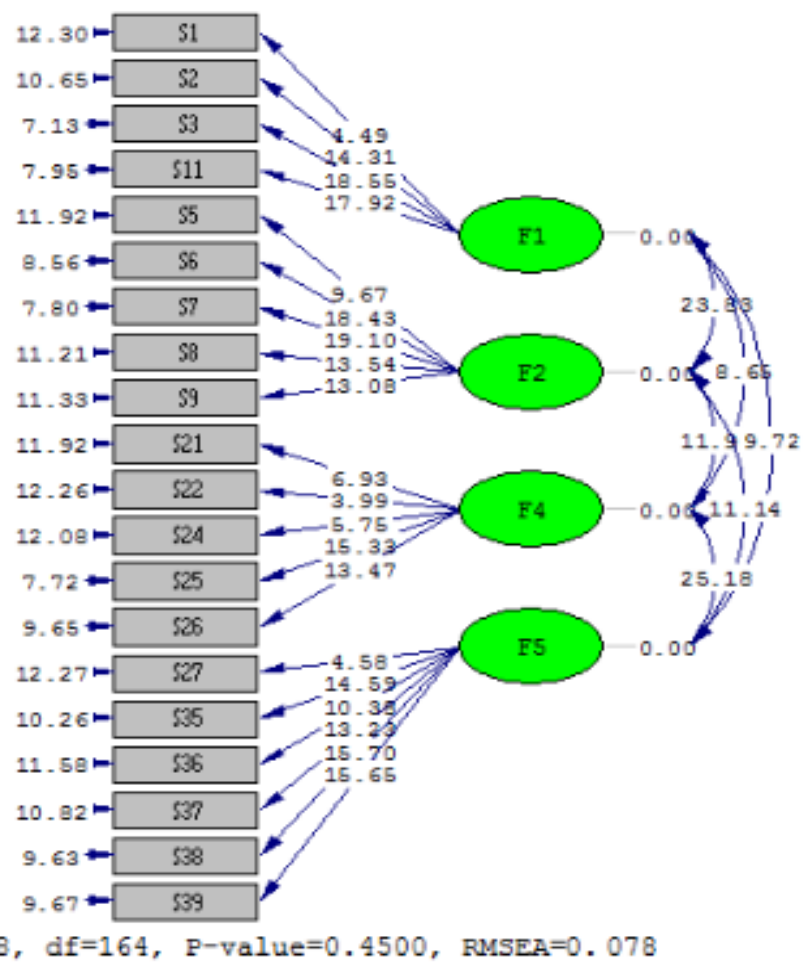

Şekil 2. Sosyal Ağlara Dayalı Öğrenme Algısı Ölçeği T değerlerine İlişkin Path Diagramı 
Ayrıca, path diyagramında standartlaştırılmış çözüm değerlerine ilişkin path diyagramı Şekil 3'te yer almaktadır:

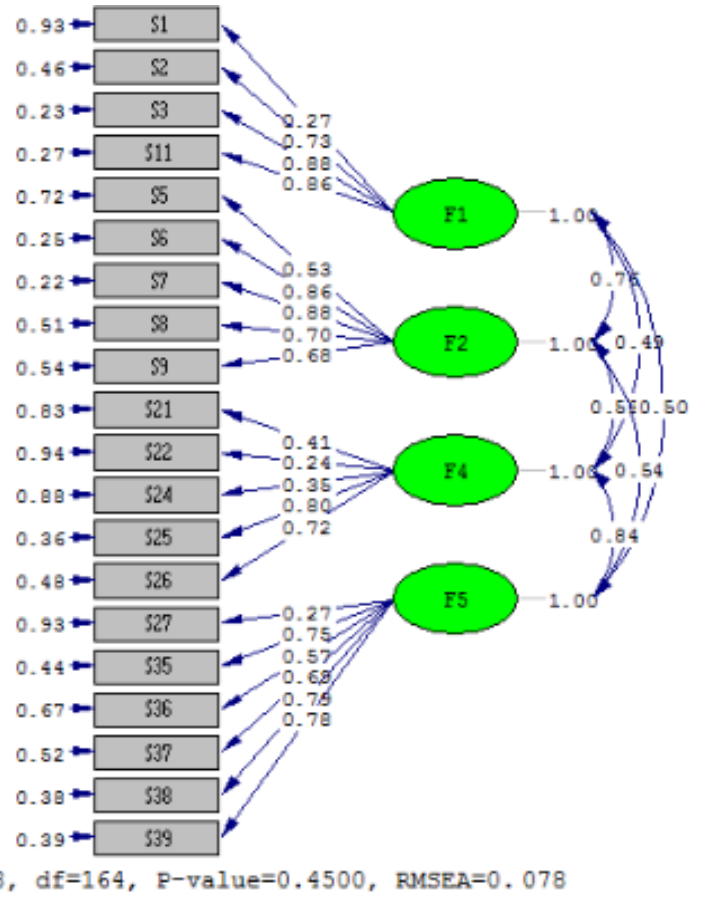

Ch1-Square $=482.78, d f=164, p-v a l u e=0.4500$, RMSEA $=0.078$

Şekil 3. Sosyal Ağlara Dayalı Öğrenme Algıısı Ölçeği Standartlaştırılmış Çözüm Değerleri

Doğrulayıcı Faktör Analizi sonucunda $\mathrm{t}$ değerleri ve standardize edilmiş değerler incelenmiş ve maddelerin 1'den düşük ve $\mathrm{t}$ değerleri açısından uygun değerlerde olduğu görülmüştür. DFA sonucunda modelin uyum değerlerinden, $x^{2} / \mathrm{sd}$ oranının 3 olduğu $(\mathrm{x} 2 / \mathrm{sd}=$ 482.78/164) ve $\mathrm{p}=.45$ olduğu saptanmıştır. İlgili alanyazında ki-kare uyum iyiliği ile serbestlik derecesi arasındaki oranın beş veya daha az ise kabul edilebilir bir değer olduğu kabul edilmektedir. $\mathrm{X}^{2} / \mathrm{sd}$ oranının 3 olması faktör yapısının modelle uyumlu olduğunu göstermektedir. Ayrıca, diğer model uyum indekslerinin incelenmesi de önemlidir. Modelin uygunluğu incelenirken kullanılan indekslerden olan GFI, CFI, NFI, RFI, IFI VE AGFI indeksleri 0 ile 1 arasında değerler alır. $\mathrm{Bu}$ değerler 1'e ne kadar yakınsa o kadar iyi uyuma karş1l1k gelir (Hooper, Coughlan ve Mullen, 2008). RMSEA içinse 0.08 kabul edilebilir uyum ve 0.05 mükemmel uyum değeri olarak kabul edilir (Şimşek, 2007). CFI ve GFI indekslerinin 1 olması durumunda model veri uyumunun mükemmel olduğunu göstermektedir (Çokluk ve diğerleri, 2016; Tabachnick ve Fidell, 2013). Model uyum indekslerine ilişkin sınır değerleri Tablo 7'de gösterilmektedir:

Tablo 7.

Doğrulayıcı Faktör Analizi Model Uyum İndeksleri Sınır Değerleri

\begin{tabular}{lll}
\hline Uyum İndeksi & Kabul edilebilir alt sınır & Mükemmel uyum \\
\hline NFI & $=0.90$ ve üzeri & 0.95 ve üzeri \\
NNFI & $=0.90$ ve üzeri & 0.95 ve üzeri \\
IFI & $=0.90$ ve üzeri & 0.95 ve üzeri \\
RFI & $=0.90$ ve üzeri & 0.95 ve üzeri \\
CFI & $=0.95$ ve üzeri & 0.97 ve üzeri \\
GFI & $=0.85$ ve üzeri & 0.90 ve üzeri \\
AGFI & $=0.85$ ve üzeri & 0.90 ve üzeri \\
RMSEA & $=0.050$ ve $=0.080$ arası & $=.000$ ve $<0.050$ aras1 \\
\hline $\mathrm{x}^{2} / \mathrm{sd}$ & Bu değer 3'ten küçük olmalı & \\
& ve anlamsiz olmalıdır. &
\end{tabular}


$\mathrm{Bu}$ çalışmada, GFI değeri 0.90 ve AGFI değeri 0.88 olarak saptanmış olup, bu değerlerin uyum için yeterli olduğu ifade edilebilir. Çalışmada, bununla birlikte, RMSEA değeri $\% 95$ güven aralığı ile 0.078 ; RMR değeri ise 0.066 olarak saptanmış olup, bu değer iyi/kabul edilebilir uyum iyiliğine karş1lık gelmektedir (Brown, 2014; Schumacher ve Lomax, 2004). CFI değerinin 0.95 'e eşit veya bu değerden büyük olması mükemmel uyuma işaret etmektedir (Thompson, 2004). Çalışmada CFI değeri 0.95 olarak saptanmıştır. Elde edilen bu değer iyi/kabul edilebilir uyum olarak değerlendirilmektedir. Bunun yanında, çalışmada NFI değeri 0.91 olarak, NNFI değeri ise 0.93 olarak hesaplanmıştır. NFI ve NNFI değerlerinin de 0.95 'e eşit veya bu değerden büyük olması mükemmel uyum iyiliğine işaret etmedir. Doğrulayıcı faktör analizi sonucunda elde edilen bulgulara bakıldığında, model sınanırken kullanılan uyum indekslerinin tamamının mükemmel uyum değerlerine yakın olduğu görülmektedir. Dolayısıyla, modelin kabulü için yeterli düzeyde istatistiksel değerler elde edilmiştir. Doğrulayıcı faktör analizi ile modelin doğrulanmasından sonra, Sosyal Ağlara Dayalı Öğrenme Alg1sı Ölçeği 20 maddelik ölçek olarak geliştirilmiştir.

\section{Sonuç}

Sosyal Web olarak adlandırılan dijital dünyada sosyal ağlarda yer alan öğrenme firsatlarına ilişkin öğretmenlik mesleğini yürütecek bireylerin farkındalıklarını belirlemek oldukça önemli hale gelmiştir. $\mathrm{Bu}$ araştırmada öğretmenlerin veya öğretmen adaylarının sosyal ağlara dayalı öğrenme algılarının belirlenmesi amacıyla bir ölçek geliştirilmiştir. Geliştirilen ölçeğin madde havuzu oluşturulması aşamasında, kritik paydaşlardan olan öğretmen adaylarının görüşleri alınmış ve alan yazında yer alan çalışmaların bulguları incelenmiştir. Böylece ölçeğin güncel çalışmaları ve paydaşların algılarını daha iyi ölçmesi sağlanmıştır. Yapı geçerliliğini test etmek üzere gerek açımlayıcı ve doğrulayıcı faktör analizlerine başvurulmuş, her bir analiz için yeterli düzeyde çalışma grubundan veri toplanmıştır. Böylece ölçeğin güncelliğinin yanı sıra ulusal düzeyde de güvenilir bir biçimde uygulanabilir olması hedeflenmiştir. Özet olarak, alan yazın taraması, kapsam geçerlilik indeksleri, örneklem yeterliliği ve faktör analizleri sonucunda $7^{\wedge} l i$ likert tipinde en düşük puanı 20; en yüksek puanı 140 olan yirmi maddeden oluşan dört faktörlü güncel ve güvenilir bir sosyal ağlara dayalı öğrenme algısı ölçeği ortaya konmaya çalışılmıştır. İlk faktördeki maddeler bireyin başkalarıyla bir etkileşim içerisinde gerçekleştirdiği öğrenmeler üzerinde odaklandığı için "etkileşime dayalı öğrenme"; ikinci faktördeki maddeler ihtiyaçlara yönelik pratiklik ve işe yararlık üzerinde odaklandığı için "kullanım kolaylığı"; üçüncü faktördeki maddeler çeşitli düzeylerdeki örtük ya da açık paylaşımlardan ortaya çıkan öğrenmeler üzerinde odaklandığı için "paylaşım"; dördüncü faktördeki maddeler ise öğrenme ortamının, öğrenme araçlarının ve zamanın özelleştirilebilmesi ile ilgili olduğu için "kişiselleştirme" olarak adlandırılmıştır. Geçerlik ve güvenirliğe ilişkin tatmin edici bulgular elde edilmekle beraber, sonraki süreçlerde elde edilen bulguarın doğrulanmasına yönelik çalışmalar yapılması yararlı olacaktır.

\section{Kaynaklar}

Akbulut, Y. (2010). Sosyal bilimlerde SPSS uygulamaları (S1k kullanılan istatistiksel analizler ve açıklamalı SPSS çözümleri). İstanbul: İdeal Kültür Yayıncılık.

Ala-Mutka, K. M., Bacigalupo, M., Kluzer, S., Pascu, C., Punie, Y. ve Redecker, C. (2009). Learning 2.0: the impact of Web 2.0 innovation on education and training in Europe. Joint Research Centre.

Armstrong, S. (2018, 4 Haziran). Negative effects of social networking sites for students. Erişim adresi: https://www.business2community.com/social-media/negative-effects-of-socialnetworking-sites-for-students-0311887

Barbour, M. K. ve Plough, C. (2009). Social networking in cyberschooling: Helping to make online learning less isolating. Tech Trends, 53(4), 56-60.

Batchelder, C. W. (2010). Social software: Participants' experience using social networking for learning (Yayımlanmamış doktora tezi). Capella Üniversitesi, Capella. 
Brown, T. A. (2014). Confirmatory factor analysis for applied research. New York: Guilford Publications.

Büyüköztürk, Ş. (2009). Sosyal bilimler için veri analizi el kitabı (10. Bask1). Ankara: Pegem Yayınları.

Carmines, E. G. ve Zeller, R. A. (1978). Reliability and validity assessment. Beverly Hills, C. A: Sage

Christensen, C. M., Horn, M. B. ve Johnson, C. W. (2008). How'disruptive innovation'will change the way we learn. Education Week, 27(39), 25-36.

Cicchetti, D. V. ve Sparrow, S. A. (1981). Developing criteria for establishing interrater reliability of specific items: applications to assessment of adaptive behavior. American Journal of Mental Deficiency, 86(2), 127-137.

Comrey, A. L. ve Lee, H. B. (1992). A first course in factor analysis. UK: Psychology Press.

Cronbach, L. J. ve Meehl, P. E. (1955). Construct validity in psychological tests. Psychological Bulletin, 52, 281-302.

Çokluk, Ö., Şekercioğlu, G. ve Büyüzöztürk, Ş. (2016). Sosyal bilimler için çok değişkenli istatistik: SPSS ve LISREL uygulamaları. Ankara: Pegem Akademi

Delfino, M. ve Persico, D. (2009). Self-regulated learning: issues and challenges for initial teacher training. Handbook of research on new media literacy at the K-12 level: Issues and challenges içinde (ss. 839-854). USA: IGI Global.

Ekici, M. (2012). Ögretim ilke ve yöntemleri dersinde sosyal ă̆lar ve işbirlikli (collaborative) ögrenme yöntemlerinin erişi düzeyine etkisi (Yayımlanmamış yüksek lisans tezi). Sakarya Üniversitesi, Sakarya

Gikas, J. ve Grant, M. M. (2013). Mobile computing devices in higher education: Student perspectives on learning with cellphones, smartphones \& social media. The Internet and Higher Education, 19, 18-26.

Gizir, S. (2005). Assessment of factors negatively effecting the communication process in Turkish state universities (Yayımlanmamış doktora tezi). Ortadoğu Teknik Üniversitesi, Ankara

Goodyear, P. ve Yang, D. F. (2009). Patterns and pattern languages in educational design. Handbook of research on learning design and learning objects: Issues, applications, and technologies içinde (ss. 167-187). IGI Global.

Greenhow, C. (2011). Online social networks and learning. On the horizon, 19(1), 4-12.

Holmes, K. M. ve O'loughlin, N. (2014). The experiences of people with learning disabilities on social networking sites. British Journal of Learning Disabilities, 42(1), 1-5.

Hooper D., Coughlan, J. ve Mullen, M. R. (2008). Structural equation modelling: Guidelines for determining model fit. Electronic Journal of Business Research Methods, 6(1), 53-60.

Hung, H. T. ve Yuen, S. C. Y. (2010). Educational use of social networking technology in higher education. Teaching in higher education, 15(6), 703-714.

Ito, M., Gutierrez, K., Livingstone, S., Penuel, B., Rhodes, J., Salen, K., Schor, J., SeftonGreen, J. ve Watkins, C. (2013). Connected learning: An agenda for research and design. Irvine, CA: Digital Media and Learning Research Hub

Johnson, L., Levine, A. ve Smith, R. (2009). 2009 Horizon report. Austin, TX: The New Media Consortium

Jovanovic, J., Chiong, R. ve Weise, T. (2012). Social networking, teaching, and learning. Interdisciplinary Journal of Information, Knowledge, and Management, 7, 39-41.

Kaplan, A. M. ve Haenlein, M. (2010). Users of the world, unite! The challenges and opportunities of Social Media. Business horizons, 53(1), 59-68.

Killion, J. (2011). The changing face of professional development. Edge: The Latest Information for the Education Practitioner, 6(5), 3-19.

Klainbaum, D. G., Kupper, L. L. ve Muller, K. E. (1987). Applied regression analysis and other multivariate methods. California: Duxbury press.

Kline, P. (1994). An easy guide to factor analysis. New York: Routledge. 
Kline, R. B. (2011). Principles and practice of structural equation modelling. New York, NY: Guilford Press.

Knezek, G., Mills, L. A. ve Wakefield, J. S. (2012). Measuring student attitudes toward learning with social media: Validation of the social media learning scale. M. Simonson (Yay. haz.). Annual convention of the Association of Educational Communications and Technology Vol. 1 içinde (ss. 127-134). Nova Southeastern University, Florida.

Kumpulainen, K. ve Sefton-Green, J. (2012). What is connected learning and how to research it? International Journal of Learning and Media, 4(2), 7-18.

Liu, Y. (2003). Developing a scale to measure the interactivity of websites. Journal of Advertising Research, 43(02), 207-217.

Luehmann, A. L. ve Tinelli, L. (2008). Teacher professional identity development with social networking technologies: learning reform through blogging. Educational Media International, 45(4), 323-333.

Margolis, A. ve Parboosingh, J. (2015). Networked learning and network science: potential applications to health professionals' continuing education and development. Journal of Continuing Education in the Health Professions, 35(3), 211-219.

McLoughlin, C. ve Lee, M. (2010). Personalised and self-regulated learning in the web 2.0 era: International exemplars of innovative pedagogy using social software. Australasian Journal of Educational Technology, 26(1), 28-43.

Mills, L. A., Knezek, G. A. ve Wakefield, J. S. (2013). Learning with social media: Measurementtools for understanding information behavior in technology pervasive environments ofthe 21st century. iConference 2013 Proceedings içinde (ss. 593-600). TX: Fort Worth.

Minocha, S. (2009). Role of social software tools in education: A literature review, Education + Training, 5(6), 353-369.

Parchoma, G. (2010). Toward diversity in researching teaching and technology philosophies in practice in e-learning communities. B. Daniel (Yay. haz.). Methods and Techniques for Studying Virtual Communities: Paradigms and Phenomena içinde (ss.61-86). Hershey, PA: IGI Global.

Polit, D. F., Beck, C. T. ve Owen, S. V. (2007). Is the CVI an acceptable indicator of content validity? Appraisal and recommendations. Research in Nursing \&Health, 30(4), 459467.

Ryberg, T., Buus, L. ve Georgsen, M. (2012). Differences in understandings of networked learning theory: Connectivity or collaboration? L. Dirckinck-Holmfeld, V. Hodgson ve D. McConnell (Yay. haz.), Exploring the Theory, Pedagogy and Practice of Networked Learning içinde (ss. 43-58). Berlin: Springer Science+Business Media.

Sabimbona, S. (2013). Sosyal ăgların ögrrenme aracı olarak değerlendirilmesi: Burundi ve Türkiye karşılaşstırması (Yayınlanmamış yüksek lisans tezi). İstanbul Üniversitesi Fen Bilimleri Enstitüsü, İstanbul.

Schumacker, R. E. ve Lomax, R. G. (2004). A beginner's guide to structural equation modeling. New Jersey: Taylor \& Francis.

Siemens, G. (2005). Connectivism: A learning theory for the digital age. International Journal of Instructional Technology and Distance Learning, 2(1), 3-10.

Şencan H. (2005). Sosyal ve davranışsal ölçümlerde güvenirlik ve geçerlik. Ankara: Seçkin Yayincilik.

Şimşek, Ö. F. (2007). Yapısal eşitlik modellemesine giriş temel ilkeler ve LiSREL uygulamaları. Ankara: Ekinox

Tabachnick, B. G ve Fidell, L. S. (2013). Using multivariate statistics. Boston: Pearson.

Tavşanc1l, E. (2002). Tutumların ölçülmesi ve SPSS ile veri analizi. Ankara: Nobel Yayıncılık.

Tezbaşaran, A. (1996). Likert tipi ölçek geliştirme kılavuzu. Ankara: TPD Yayınları.

Thompson, B. (2004). Exploratory and confirmatory factor analysis: Understanding concepts and applications. Washington DC: American Psychological Association. 
Thorndike R. L.ve Hagen, E. (1977). Measurement and evaluation in psychology and education. Newyork: Chapman and Hall Ltd.

Veletsianos, G. (2011). Designing opportunities for transformation with emerging technologies. Educational Technology, 51(2), 41-46.

Waltz C. F., Strcikland O. L. ve Lenz E. R. (2010). Measurement in nursing and health research. New York: Springer Publishing Company.

Webb, E. (2009). Engaging students with engaging tools. Educause Quarterly, 32(4), 1-7.

\section{Extended Abstract}

\section{Introduction}

The use of social networks for learning purposes, which have become widespread nowadays is seen as important and valuable in terms of informal learning. It is seen that social networks and social media applications are now becoming part of a world called Social Web (Web 2.0); therefore, educators attempt to make learning unique and customized due to digital natives. McLoughlin and Lee (2010) state that social-based Web 2.0 tools and technologies support informal speech, reflective dialogue, collaborative content production, and access to many ideas and presentations. Appropriate use of these tools, by supporting the learner, autonomy and participation in social networks, the actual control given to the learner is emphasized. Web 2.0 tools make learners independent from physical, geographic, institutional and organizational boundaries. According to McLoughlin and Lee, for this Web 2.0-based self-regulated learning to be productive, learners need to learn what tools / content they can select and personalize, and learn from which places / resources they can get help. The emerging digital practices based on socio-technology reveal the need for more personalized, social and more participation-based educational insights.

Margolis and Parboosingh (2015) emphasize that social networks exist in a context (such as an organization, community, profession) and for specific purposes (such as sustainable professional development); network structures can be customized according to certain possible purposes. According to Margolis et al. (2015), professional experts with common interests and practices - can create networks in a collective manner in these networks -like actors acting the same complex adaptive systems; they can exhibit a management process in a conscious or unconscious way, maintain the stability of their networks, establish appropriate connections with organizations and communities that are important for their purposes, and encourage interaction between members, based on trust and participation. According to Ito et al. (2013), the most effective and meaningful forms of learning are learning situations where learners have access to rich social support, the subject area is relevant and allows interaction. Connected learning focuses on the connection between different areas of knowledge, culture and social practice to provide meaningful and sustainable learning by combining motivation, content and a social, interest-based, formal education field.

\section{Method}

This research aims to develop a scale for determining social networks-based learning perception of pre-service teachers. As a result of literature review and discussions with pre-service teachers, a pool of 47 items have been created. For expert view, 6 experts give their ideas using 7 point likert scale. Then, validity index of the each item and overall scale have been calculated. Scale is applied to two different groups. For the construct validity of the scale, exploratory factor analysis is conducted with data collected from 350 pre-service teachers and confirmatory factor analysis is done with another study group including 325 pre-service teachers.

\section{Result and Discussion}

The assumptions necessary for the factor analysis related to collected the data are controlled. For this purpose, missing value analysis, sampling size, outlier analysis, normality, multivariate normality / linearity and multicollinearity are analyzed. In this study, basic component analysis 
is done and a varimax rotation is performed as a factor rotation method based on the hypothesis that the factors can be unrelated (Akbulut, 2010). It is generally claimed that the load value of an item is acceptable up to 0.30 (Çokluk et al., 2016). In this study, the factor cut-off point is accepted as 0.40 . In addition, an item should not be categorized under more than one factor. The difference between factor loads should be at least 0.10 ; in order not to be referred as overlapping items in the literature (Bütüner and Gür, 2007).

Factors with a factor load of less than 0.40 are omitted and items including $5,12,13,14,15,18,19$ and 29 items which are overlapping are discarded and factor analysis is repeated. This procedure is repeated multiple times and as a result, 20 items with an eigenvalue greater than 1 are grouped under 4 factors. These 4 factors explain 58,14\% of the scale variance. The Kaiser-Meyer Olkin [KMO] coefficient and Barlett's Sphericity test are used to evaluate whether the observations in the AFA group are appropriate for factor analysis. The KMO and Barlett Sphericity Tests for the Social Networks-Based Learning Perception Scale show that $\mathrm{KMO}$ value is very good $(\mathrm{KMO}=0.92)$ which indicated sampling adequacy. The chi-square value of the Bartlett sphericity test is found to be 9074,288 ( $\mathrm{p}<.001$ ). Also, as Bartlett test is found to be significant, it indicates that the data come from a multivariate normal distribution (Thompson, 2004).

The model is verified with confirmatory factor analysis and fit indices used for testing the model are sufficient for the acceptance of the model. Social Networks-Based Learning Perception Scale is developed as a 20-item four-factor scale. Cronbach Alpha coefficient correlation of scale is found out to be $(\alpha)=.905$ and explained variance to be $(58.14 \%)$. Additionally, Pearson Moment Correlation analysis is done and it is found out that there is a high level of correlation between individual items and overall score. This four-factor structure, with the emerging modification indexes, indicate that the Social Networks-Based Learning Perception Scale is valid and reliable and can be used in future research.

\section{EK: Sosyal Ağlara Dayalı Öğrenme Algısı Ölçeği}

Maddeler

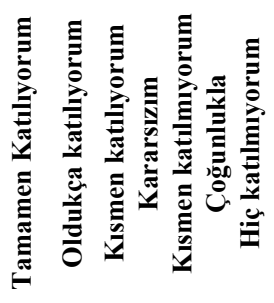

$\begin{array}{lllllll}7 & 6 & 5 & 4 & 3 & 2 & 1\end{array}$

\footnotetext{
1. Sosyal ağlarda, daha tecrübeli kullanıcıların deneyim ve bilgilerinden yararlanabildiğim

๕̊ için daha iyi öğrenirim.

: 2 . Sosyal ağlarda, diğer kullanıcılardan etkin dönüt alabildiğim için daha iyi öğrenirim.

코 3. Sosyal ağlarda, karşımdakine kendimi daha rahat ifade edebildiğim için daha iyi

خ্ট̈ ögrenirim.

. 4. Sosyal ağlar sayesinde, daha etkin iletişim ve etkileşimde bulunduğum için daha iyi

\&̈ğrenirim.

5. Sosyal ağlarda diğer kullanıcılara çevrimiçi veya çevrimdışı soru sorabildiğim için daha iyi öğrenirim.
}

6. Sosyal ağlarda, etkili kaynaklara erişebildiğim için daha iyi öğrenirim.

7. Sosyal ağlarda, bilgiye daha rahat erişebildiğim için daha iyi öğrenirim.

8. Sosyal ağlarda, daha etkili katılım imkânı olduğu için daha iyi öğrenirim.

9. Sosyal ağlarda, konu uzmanlarına erişim ve takip kolay olduğu için daha iyi öğrenirim. 
10. Sosyal ağlarda çeşitli görevlerle (proje, ödev vb.) ilgili yardım alabildiğim için daha iyi öğrenirim.

11. Sosyal ağlar diğer kullanıcılarla paylaşımlara (link, belge vb.) izin verdiği için daha iyi छ̈ögrenirim.

¿ 12 . Sosyal ağlarda bir konuya ilişkin iyi örnekler paylaşıldığı için daha iyi öğrenirim.

13. Sosyal ağlarda güncel gelişmeler anında paylaşıldığı için daha iyi öğrenirim.

14. Sosyal ağlardaki kullanıcılarla benzer ilgilere sahip olup ortak amaçları paylaştığım için daha iyi öğrenirim.

15. Sosyal ağlarda, kendi öğrenme deneyimimi düzenleyebildiğim için daha iyi öğrenirim

16. Sosyal ağlarda, kendi anlama biçimlerimin farkına vardığım için daha iyi öğrenirim.

17. Sosyal ağlarda, esnek bir öğrenme ortamı olduğu için daha iyi öğrenirim.

$\stackrel{\mathscr{\sigma}}{=} 18$. Sosyal ağlarda, farklı düşünme biçimleriyle karşılaştığım için daha iyi öğrenirim.

19. Sosyal ağlarda öğrenme sorumluluğu bireyde olduğu için, burada gerçekleşen

ögrenmelerim daha kalıcı olmaktadır

20. Derslerin sosyal ağlarla desteklenmesi durumunda, derslerde daha iyi öğrenirim. 